Kuzkov' ${ }^{1}, V_{\text {., Sodnik }}{ }^{2}$, Z., and Kuzkov ${ }^{1}, \mathrm{~S}$.

${ }^{1}$ Main Astronomical Observatory, the NAS of Ukraine, 27, Akademika Zabolotnoho St., Kyiv, 03680, Ukraine, tel.: +38 (044) 526-08-69

${ }^{2}$ European Space Research and Technology Centre, ESA, Postbus 299, 2200 AG Noordwijk, The Netherlands, tel.: +31071 5656565

\title{
DIRECT MEASUREMENTS OF LASER COMMUNICATION POINT-AHEAD ANGLES FROM THE ARTEMIS GEOSTATIONARY SATELLITE THROUGH CLOUDS
}

\begin{abstract}
Laser experiments with ARTEMIS geostationary satellite have been performed in partly cloudy weather using the developed system for the telescope. It has been found that the part of the laser beam is observed simultaneously at the points in direction of the velocity vector where the satellite would arrive at when the laser light reaches the telescope. These results agree with the theory of relativity for light aberration in transition from fixed to moving coordinate system. Observation results open the way for research and development of systems to compensate atmospheric turbulence in laser communications between ground stations and satellites through the atmosphere.
\end{abstract}

Keywords: astronomy, satellites, laser radiation, aberration, bias angles, and relativistic processes.

\section{INTRODUCTION}

In July 2001, the European Space Agency (ESA) geostationary Earth orbiting (GEO) Advance data-Relay and Technology Mission Satellite (ARTEMIS) was launched with on-board laser communication terminal OPALE [1]. 1789 laser communications sessions were performed between ARTEMIS and SPOT-4 (PASTEL) from 01 April 2003 to 09 January 2008 with total duration of 378 hours. Laser communication experiments between ESA's Optical Ground Station (OGS) and ARTEMIS were also performed under various atmosphere conditions [2, 3, 4]. The free space laser communication systems have some advantages in comparison with the radio frequency communication systems, which is a result of much higher carrier frequency (up to some hundreds of $\mathrm{THz}$ ) for the laser communication and a possibility of higher communication rates up to $\mathrm{N} \times 10$ Gbps per each communication channel. Ground-to-satellite optical link tests between the Japanese laser

(c) V. KUZKOV, Z. SODNIK, S. KUZKOV, 2017 communication terminal and the European geostationary satellite ARTEMIS has been performed [5]. The German Space Agency (DLR) and the Tesat-Spacecom have designed space laser communication terminals using BPSK (binary phase shift keying) modulation and established laser communication links between LEO satellites TerraSAR-X and NFIRE (achieving data transfer rates of $5.6 \mathrm{Gbps}$ at distance $5,100 \mathrm{~km}$ ), in 2008. ESA is now developing the European Data Relay Satellite (EDRS) system with the use of laser communication technology to transmit data from LEO satellites to two geostationary satellites (EDRS-A and EDRS-C) with data rates of $1.8 \mathrm{Gbps}$ at LEO-to-GEO link distance up to $45,000 \mathrm{~km}$ by using improved Tesat-Spacecom laser communication terminals.

In October 2013, NASA demonstrated transmission of data from lunar orbit LADEE spacecraft to NASA OGS with a rate of 622 Mbps by using two simultaneous channels and pulsed position modulation at a distance up to 239,000 miles. The tests have been also performed for providing 
continuous measurements of the distance by the same laser beams from the Earth to the LADEE spacecraft with an accuracy of less than $10 \mathrm{~mm}$.

The amount of information from telecommunication satellites in GEO constantly increases and there is a demand for a high-rate information transmission from the ground, in particular, by laser link via atmosphere. To mitigate the influence of atmospheric conditions on ground-to-space and space-to-ground laser communication, it would be desirable to have a network of OGS with different atmosphere conditions.

\section{START OF MAO DEVELOPMENT}

ESA's OGS uses the Coude focus of a $1 \mathrm{~m}$ telescope located at an altitude of $2400 \mathrm{~m}$ above sea level. In 2002, the Main Astronomical Observatory (MAO) of the National Academy of Science of Ukraine started the development of a ground laser communication system for the $0.7 \mathrm{~m}$ AZT-2 telescope using the Cassegrain focus of a $0.7 \mathrm{~m}$ telescope at an altitude of $190 \mathrm{~m}$ above sea level. Some design works have been performed [6-9]. Therefore, it was interesting to compare the influence of atmosphere conditions in different atmosphere regions. Comparative study of atmosphere turbulence at ESA's OGS and MAO telescope has been performed as well [10-11].

Some experiments with ARTEMIS satellite started. [12]. The precision pointing and tracking system for AZT-2 telescope and other systems were developed [13, 14, 15].

\section{LASER COMMUNICATION EXPERIMENTS WITH ARTEMIS}

As a result, the MAO developed a compact laser communication system called LACES (Laser Atmosphere and Communication Experiments with Satellites) [16]. The work was supported by the contracts with European Space Agency and $\mathrm{Na}-$ tional Space Agency of Ukraine. Laser experiments between MAO and ARTEMIS have been performed. Laser links between LACES terminal of AZT-2 telescope and OPALE communication terminal of ARTEMIS have been established [17].
To mitigate the influence of atmospheric conditions on ground-to-space and space-to-ground laser communication, it would be desirable to have a network of OGS in different atmosphere regions. Synchronous tests of laser active ARTEMIS Satellite by ground network of optical ground stations of Ukraine have been carried out as well [18].

\section{LASER EXPERIMENTS WITH ARTEMIS IN CLOUDY CONDITIONS}

Some laser experiments with ARTEMIS satellite were performed in cloudy conditions at an altitude above the horizon from 22 to 25 degrees. The laser beams from the satellite were recorded through clouds by tracking CCD camera with $732 \times 582$-pixel censor. The calculated pixel scale in the focal plane was 0.327 arc-sec per pixel for $X(\alpha)$ and 0.316 arc-sec per pixel for $Y(\delta)$ directions. The splitting of laser beam from the satellite was observed in $X$ (right ascension) and $Y$ (declination) directions. The splitting along the declination direction may be interpreted as result of extreme refraction in the atmosphere at low altitudes above the horizon.

The angular splitting between $\mathrm{A}$ and $\mathrm{C}$ components for image art3174 and between $\mathrm{A}$ and $\mathrm{B}$ components of image art4331 was: $\Delta X(\alpha)=6$ pixels or 1.962 arc-sec in the right ascension (ahead angle) directions (Fig. $1 a, b$ ).

The angular splitting between $\mathrm{A}$ and $\mathrm{C}$ components of the image art3308 was also $\Delta X(\alpha)=$ 1.962 arc-sec (Fig. 2, $a$ ). Maximum signal for $A$ component is 47579 levels for the analog to digital convertor $(A D C)$ and 19486 levels for $C$ component. Signal noise was approximately 60 levels. So, for image art3308 the signal/noise ratio was 793 for $A$ component and 325 for $C$ component. (Fig. 2, $b$ ). The next beacon peaks observed through clouds can be seen in image art3350 (Fig. 3, a) and image art3351 (Fig. 3, b). For these images the angular splitting between $\mathrm{A}$ and $\mathrm{B}$ components was also $\Delta X(\alpha)=1.962$ arc-sec.

As a result, a small part of the laser beam has been found to be observed ahead of the velocity vector simultaneously in the point the satellite would ar- 

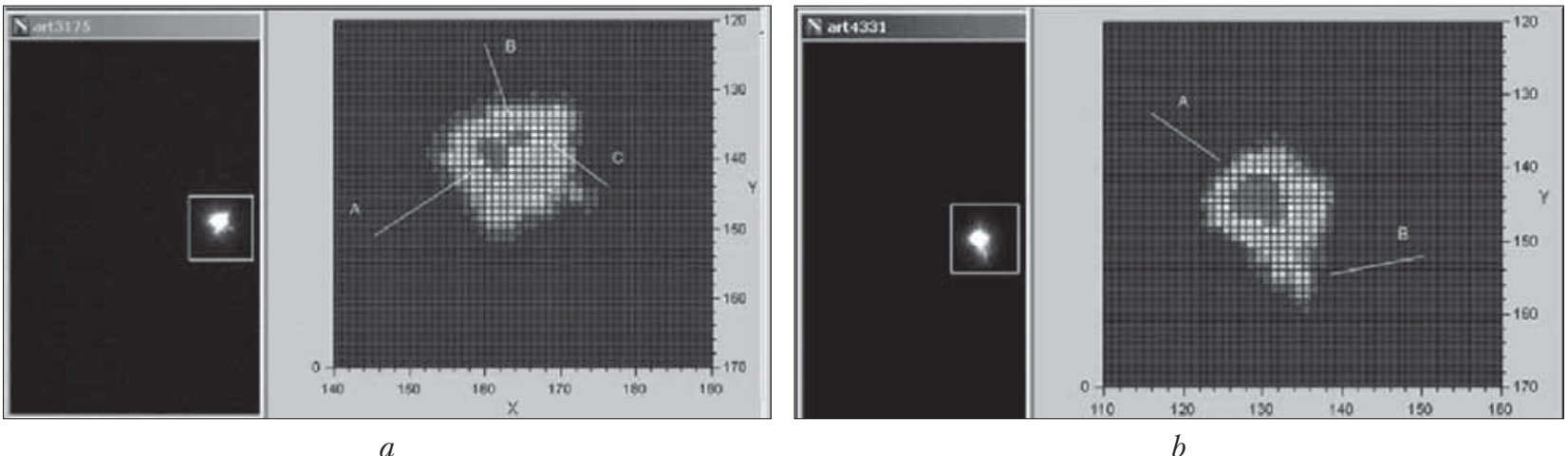

Fig. 1. The 2-D view of the images art3175 (a) and art $4331(b)$
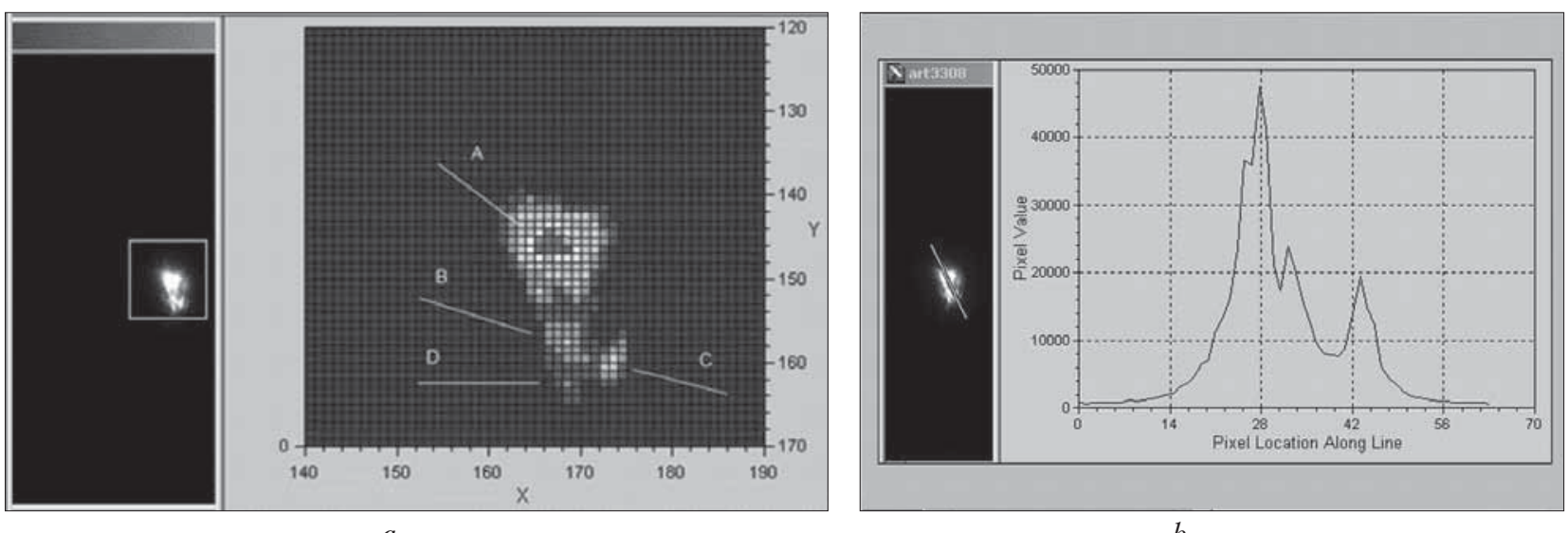

$a$

Fig. 2. The 2-D view of the image art3308 ( $a$ ) and Sliced line of the A and C components $(b)$
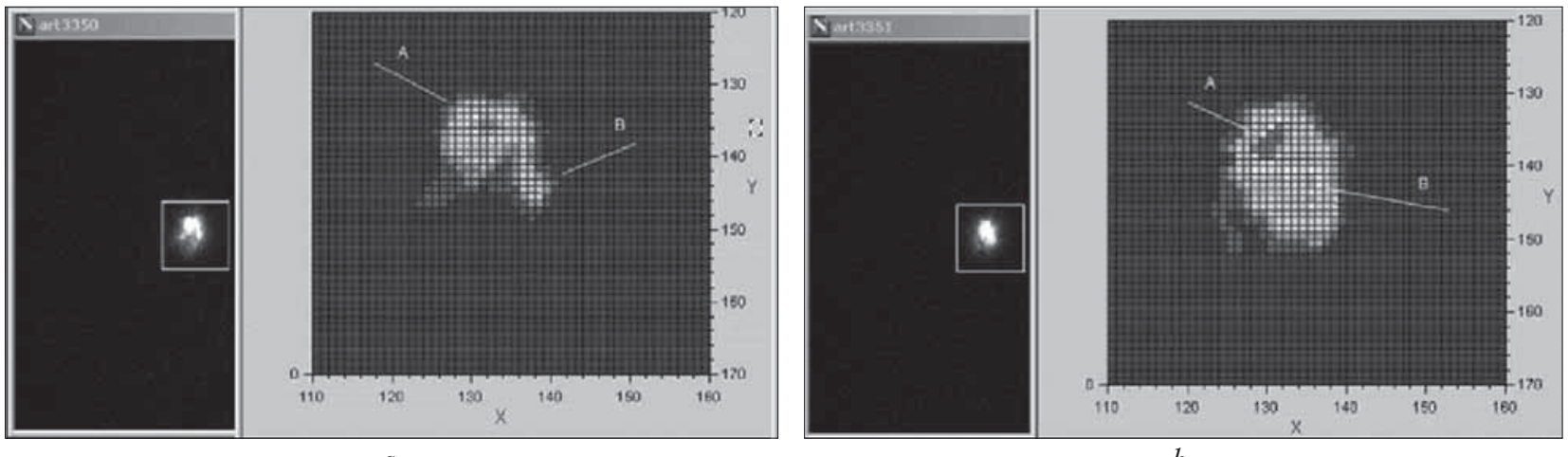

Fig. 3. The 2-D view of the images art3350 ( $a$ ) and art3351 (b)

rive at for the time of propagation of laser light from the satellite to the telescope [19, 20] (Fig. 4, a).

For precision tracking of the satellite right ascension angles $(\alpha)$, hour angles $(H)$, declinations $(\delta)$ of the telescope and distances $L$ to the satellite, as well as time of propagation Tsig of laser radiation from the satellite to the telescope primarily were calculated. Tsig $=L \times \mathrm{Vsig}^{-1}$ were $\mathrm{Vsig}=C$ which 

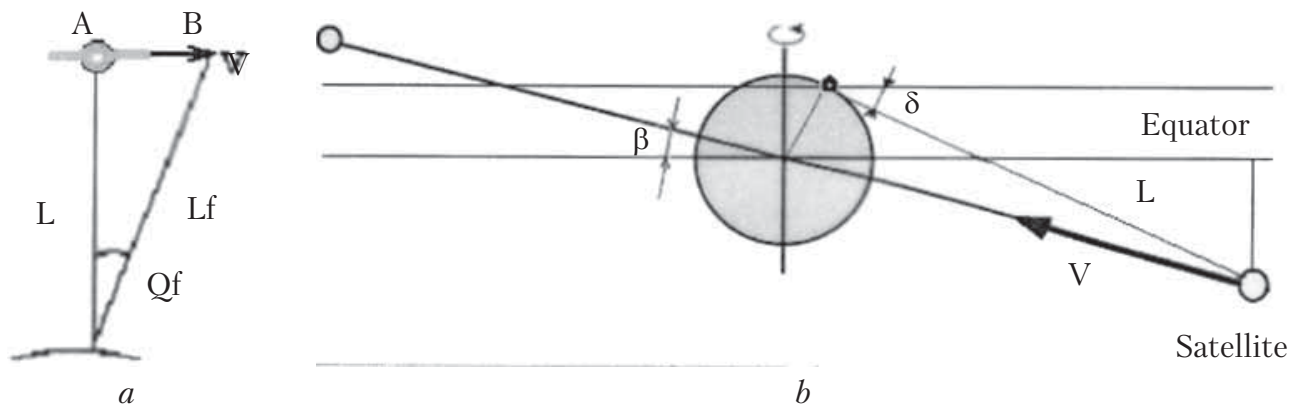

Fig. 4. Point-ahead angle of the satellite ( $a$ ) and position of the satellite orbit to Equator $(b)$

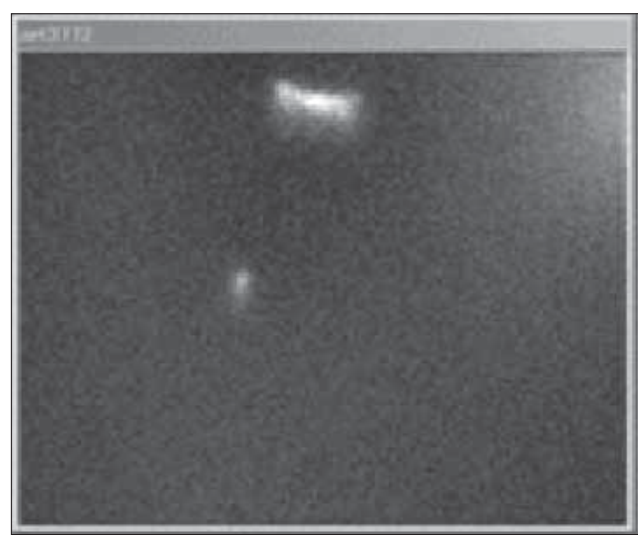

$a$

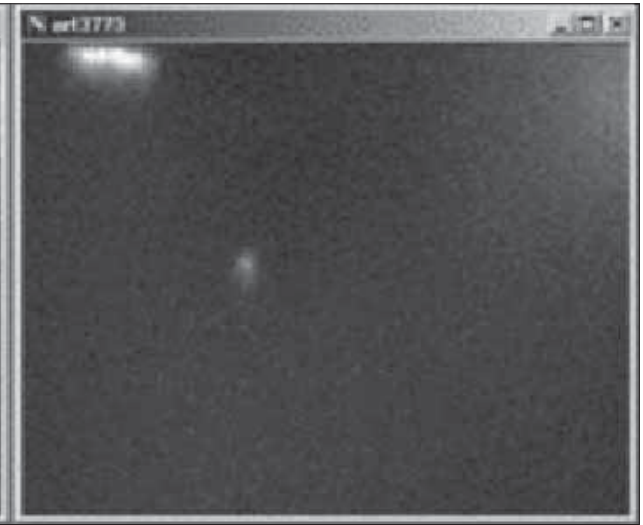

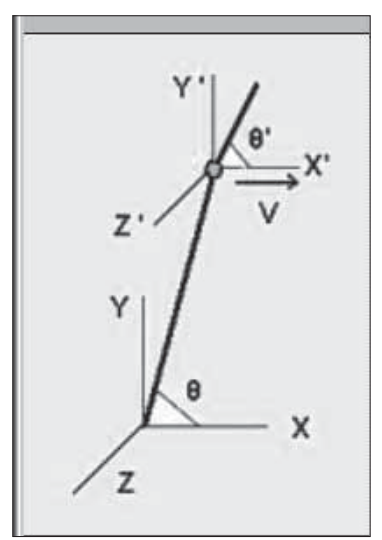

$b$

Fig. 5. Star moving near ARTEMIS position (a); the aberration angle for the satellite and coordinate systems $(b)$

is the velocity of light $\left(299,792 \mathrm{~km} \times \mathrm{s}^{-1}\right)$ in space. From NORAD 2-line elements of the satellite data we know that velocity of the satellite is $3.07 \mathrm{~km} \times \mathrm{s}^{-1}$. The point-ahead angle $Q f$ is determined as $Q f=$ $=\mathrm{Lab} \times L^{-1}$ or $Q f=V \times C^{-1}$. The result is $Q f=$ $=2.112$ arc-sec. The direction of moving satellite may see from directions of moving star observed between of clouds (Fig. 5, $a$ ).

The point-ahead angle $Q f$ was calculated for orbit plane of the satellite that has inclination $\beta=$ $=10^{\circ} 20^{\prime} 28^{\prime \prime}$ to the Earth equator plane (Fig .4, $b$ ). The velocity vector of the satellite has the same inclination. It is necessary to know the projections of Lab on the right ascension (hour angle) direction of the telescope for performing further correction of the hour angle (on the point-ahead angle) of the telescope. The corrected point-ahead angles $Q f \alpha \beta$ on hour angle direction are also determined and result is $Q f \alpha \beta=2.078$ arc-sec. It is close to the point-ahead angle previously calculated by us. The ahead angle $Q f \alpha \beta$ for the right ascension direction has been computed as well. For different declinations $(\delta)$ of the satellite observed the ahead angles are $Q f \alpha \beta \delta$. The results of observed and calculated point-ahead angles are presented in Table.

In the observations of propagation of laser light from the satellite to MAO OGS through clouds, the positions of ARTEMIS that were equivalent to the calculated point-ahead angle for the satellite were directly observed. $Q f \alpha \beta \delta$ are corrected point-ahead angles for telescope coordinating system; $\Delta \alpha$ is observed point-ahead angles for telescope coordinate system. The differences from observed and calculated point-ahead angles are from 0.009 to 0.020 arc-sec and up to 0.034 arc-sec for image art4331 with smaller $\delta$ of -14.577 . The accuracy of observations is limited by size of 1 or 2 pixels and is $0.164-0.327$ arc-sec along of $X$ axis of the 
Laser ahead angles in $\mathrm{X}(\alpha)$ direction

\begin{tabular}{|c|c|c|c|c|c|c|c|}
\hline \# Art - image & $\Delta \alpha$, arc-sec & $\mathrm{L}, \mathrm{km}$ & Hvel, "'s ${ }^{-1}$ & Tsig, $\mathrm{s}$ & $\delta, \mathrm{deg}$ & Qf,arc-sec & Qf $\alpha \beta \delta, \operatorname{arc}-\mathrm{sec}$ \\
\hline art3175 & 1.977 & 39351 & -0.197 & 0.1313 & -17.086 & 2.112 & 1.986 \\
art3307 & 1.977 & 39256 & -0.112 & 0.1309 & -16.081 & 2.112 & 1.997 \\
art3308 & 1.977 & 39256 & -0.112 & 0.1309 & -16.081 & 2.112 & 1.997 \\
art3350 & 1.977 & 39250 & -0.107 & 0.1309 & -16.016 & 2.112 & 1.997 \\
art3351 & 1.977 & 39250 & -0.107 & 0.1309 & -16.015 & 2.112 & 1.997 \\
art4331 & 1.977 & 39117 & -0.003 & 0.1305 & -14.577 & 2.112 & 2.011 \\
\hline
\end{tabular}

CCD camera. The accuracy of tracking the satellite was measured for Session 1. Positions of laser beacon through clouds were measured for images art3176 and art3229 with record time $19 \mathrm{~h}: 03 \mathrm{~m}: 03 \mathrm{~s}$ and $19 \mathrm{~h}: 06 \mathrm{~m}: 33 \mathrm{~s}$, respectively. Differences of positions between observed beacon in these images were $\Delta X(\alpha)=4.532$ arc-sec and $\Delta Y(\delta)=3.735$ arc-sec. As a result, the drift of tracking was 0.021 arc-sec per second in the $X(\alpha)$ axis and 0.018 arc-sec per second in the $Y(\delta)$ axis.

However, from (Fig. 4. $a$ ) one can see that $L f>L$, Tsig for $L>$ Tsig for $L f+L(A-B)$. How can the observed results be explained from the standpoint of modern physics?

\section{DERECTLY OBSERVED LASER LIGHT ABERRATION}

The stellar aberration, as a result of the Earth motion around of the Sun, was discovered by James Bradley with results presented in Bradley J. (1727) [21]. We study the motion of ARTEMIS satellite in space around of Earth. In accordance with the theory of relativity, the aberration of light changes the direction of light during the transition from immovable to movable coordinate systems. We have two coordinate systems. The first one $\left(X^{\prime}, Y^{\prime}\right.$, and $\left.Z^{\prime}\right)$ is for the satellite (Fig. 5. $b$ ). The second coordinate system $(X, Y$, and $Z$ ) is for the telescope. The light direction $\theta^{\prime}$ in the satellite coordinate system is determined by Eq. (1) in accordance with the description presented in C. Moller (1972) [22].

$$
\tan \left(\theta^{\prime}\right)=\frac{\sin (\theta) * \sqrt{1-(\mathrm{V} / \mathrm{C})^{2}}}{\cos (\theta)+\mathrm{V} / \mathrm{C}},
$$

$$
\tan \left(\theta^{\prime}\right)=C / V
$$

when the satellite is tracked, the $X$ axis is parallel to $X^{\prime}$ and the $Y$ axis is parallel to $Y^{\prime}$. The satellite center is equivalent to the center of $X^{\prime}, Y^{\prime}, Z^{\prime}$ coordinates calculated for every time of observations. The center of our telescope CCD camera is equivalent to the center of $X, Y, Z$ coordinates. As a result, the angle $\theta$ is $90^{\circ}$. It is in good agreement with the calculated angle $\theta$ ' determined by aberration equation (2) $(V<<C)$. The light aberration angle (the point-ahead angle) is determined as $\Delta \theta=\theta-\theta^{\prime}$. In our case $\Delta \theta=2.112 \operatorname{arc}-\sec (V=$ $=3.07 \mathrm{~km} / \mathrm{s}, C=299,792 \mathrm{~km} / \mathrm{s})$. Thus, $\Delta \theta=Q f$ as calculated previously. We directly observed the laser light aberration as result of satellite moving with angular velocity close to angular rotation of the Earth. For the time being, no other examples of direct observations of this aberration for satellites have been known [20].

\section{CONCLUSIONS}

A small part of laser beam has been found to be observed ahead of the velocity vector in the point the satellite would arrive at for the time of propagation of the laser light from the satellite to the telescope. The point-ahead angles and the laser light aberration as result of satellite moving with angular velocity close to angular rotation of the Earth have been directly observed. No other examples of direct observations of laser radiation from point-ahead angles and aberration of laser light for satellites have been known so far.

The turbulence conditions in ahead points are very important for the development of systems for 
compensation of turbulence. To know the conditions of atmosphere in ahead-angle points is very useful for laser ranging, communication from ground stations to satellites, and for deep space missions. The observed results open ways for the research and development of systems to compensate atmospheric turbulence in ahead points during laser ranging and communications between ground stations and satellites through the atmosphere.

\section{ACKNOWLEDGMENT}

The authors would like to thank Vincenzo Caramia from Redu Space Services S.A., ESA, Redu, Belgium, for his assistance during the preparation of laser experiments with ARTEMIS; S.P. Pukha and D.V. Volovyk from the National Technical University KPI for their considerable contribution into the development of our optical ground system; and Prof. Ya.S. Yatskiv for organizational support during the development of laser ground communication system.

\section{REFERENCES}

1. Tolker-Nielsen T., Oppenhauser G. In-orbit test result of an operational optical inter satellite link between ARTEMIS and SPOT4, SILEX. Proc. SPIE. 2002. Vol. 4635. P. 1-15.

2. Reyes M., Sodnik Z., Oppenhause G., Lopez P., Alonso A., Viera T. Preliminary results of the in-orbit test of ARTEMIS with the Optical Ground Station. Proc. SPIE. 2002. Vol. 4635. P. 38-49.

3. Romba J., Sodnik Z., Reyes M., Alonso A., Bird A. ESA's Bidirectional Space-to-Ground Laser Communication Experiments. Proc. SPIE. 2004. Vol. 5550. P. 287-298.

4. Reyes M., Alonso A., Chueca S., Fuensalida J., Sodnik Z., Cessa V., Bird A., Comeron A., Rodriguez A., Dios V., Rubio J. Ground to space optical communication characterization. Proc. SPIE. 2005. Vol. 5892. P. 589202-1589202-16.

5. Toyoshima M., Yamakawa S., Yamawaki T., Arai K., Reyes M., Alonso A., Sodnik Z. Demelenne B. Ground-to-satellite optical link tests between the Japanese laser communication terminal and the European geostationary satellite ARTEMIS. Proc. SPIE. 2004. Vol. 5338A. P.1-15.

6. Kuzkov V., Medvedskii M., Yatskiv D., Suberlak V., Glushchenko Yu., Peretyatko M., Eremenko N. Preparation for optical Communication Experiments with the Geostationary Satellite ARTEMIS. Space science and technology. 2003. No. 4. P. 79-83.
7. Kuzkov V.P., Nedashkovskii V.N. Receiving system for ground - space laser communication. Space science and technology. Suppl. 2003. No. 2. P. 106-109.

8. Kuzkov V.P., Nedashkovskii V.N. A Receiver with an Avalanche Photodiode for the Optical Communication Channel from a Geostationary Satellite. Instruments and Experimental Techniques. 2004. No. 4. P. 513-515.

9. Kuzkov V.P., Nedashkovskii V.N., Savenkov S.N., Kuzkov S.V. Investigation of the polarization of the laser transmitting module for communication experiments with the geostationary satellite ARTEMIS (ESA). Space science and technology. 2006. 12. No. 1. P. 23-28.

10. Kuzkov V., Andruk V., Sizonenko Yu., Sodnik Z. Investigation of Atmospheric Instability for Communication Experiments with ESA's Geostationary Satellite ARTEMIS. Kinematics and Physics of Celestial Bodies. Suppl. 2005. No. 5. P. 561-565.

11. Kuzkov V., Andruk V., Sodnik Z., Sizonenko Yu., Kuzkov S. Investigating the correlation between the motions of the images of close stars for laser communications experiments with the Artemis satellite. Kinematics and Physics of Celestial Bodies. 2008. Vol. 24, Issue 1. P. 56-62.

12. Kuzkov V., Sodnik Z., Kuzkov S., Volovyk D., Pukha S. Laser communication experiments with a geostationary satellite from a ground telescope. Space science and technology. 2008. 14. No. 2. P. 51-55.

13. Kuzkov V.P., Kuzkov S.V., Sodnik Z., Volovyk D.V., Pukha S.P. Pointing and tracking systems of the telescope for laser communication experiments with a geostationary satellite. Space science and technology. 2009. 15. No. 5. P. $68-73$.

14. Kuzkov S.V., Kuzkov V.P., Sodnik Z., Volovyk D.V., Pukha S.P., Kleshchonok V.V. A precise pointing and tracking system for photometric and coordinate measurements of high-earth-orbit satellites. Space science and technology. 2013. No. 3. P. 61-67.

15. Kuzkova N., Yakunov A., Kuzkov V., Medvedsky M. Development of cooling receiving system with avalanche photodiode for satellite laser ranging and communications. Proc. OSA International Conference: Application of Lasers for Sensing \& Free Space Communication Topical meeting, October 27-31, 2013, Paris, France, Paper ID: 1765715. P. 1-4. http://www.opticsinfobase.org/abstract. cfm?URI=LSC-2013-LTu2B.4

16. Kuzkov V., Volovyk D., Kuzkov S., Sodnik Z., Pukha S., Caramia V. Laser Ground System for Communication Experiments with ARTEMIS. Proc. International Conference on Space Optical Systems and Applications (ICSOS) 2012, 3-2, Ajaccio, Corsica, France, October 9-12 (2012). Paper ID: P3-2. P. 1-9. http://icsos2012.nict.go.jp/pdf/ 1569606121.pdf

17. Kuzkov S., Sodnik Z., Kuzkov V. Laser Communication Experiments with Artemis Satellite. Proc. of 64th International Astronautical Congress (IAC), Sept. 23-27, 2013, 
Beijing, China, Space communication and navigation symposium (B2). Advanced Technologies for Space Communications and Navigation (3), IAC-13-B2.3.8. Paper ID: 16572. P. 3180-3187. 2013.

18. Kozyryev Ye., Sybiryakova Ye., Shulga A., Kuzkov V., Kuzkov S., Lopachenko V., Kozhukhov A., Rikhal'sky V., Caramia V. Synchronous Tests of Laser Active ARTEMIS Satellite at Different Ground Stations. Proc. International Conference on Space Optical Systems and Applications (ICSOS) 2014, P-3, Kobe, Japan, May 7-9 (2014). Paper ID: P-3. P. 1-5. 2014. http://icsos2014.nict.go.jp/ contents/pdf/P-3.pdf

19. Kuzkov V., Sodnik Z., Kuzkov S., Caramia V. Laser Experiments with ARTEMIS Satellitein Cloudy Conditions. Proc. International Conference on Space Optical Systems and Applications (ICSOS) 2014, Kobe, Japan, May 7-9 (2014). Paper ID: S4-4. P. 1-8. 2014. http://icsos2014. nict.go.jp/contents/pdf/S4-4.pdf

20. Kuzkov V., Kuzkov S., Sodnik Z. Direct measurements of laser light aberration from the ARTEMIS geostationary satellite through thin clouds. E-print arXiv:1512.08128. Publication date: 12/2015. P. 1-7.

21. Bradley J. Account of a New Discovered Motion of the Fix's Stars. Phil. Trans. R. Soc. 1727. No. 35. P. 637-661.

22. Moller C. The Theory of relativity. Second edition. Clarendon Press Oxford. 1972. 2.11. The Doppler effect. Aberration of light.

\section{В.П. Кузьков ${ }^{1}$, 3. Соднік ${ }^{2}$, С.В. Кузьков ${ }^{1}$}

${ }^{1}$ Головна астрономічна обсерваторія НАН України, вул. Академіка Заболотного, 27, Київ, 03680, Україна, тел.: +38 (044) 526-08-69

${ }^{2}$ Свропейський космічний дослідницький і технологічний центр, ЭКА,

Пошта 299, 2200 АГ Нурдвік, Нідерланди, тел.: +310715656565

\section{ПРЯМЕ ВИМІРЮВАННЯ ЛАЗЕРНИХ КОМУНІКАЦІЙНИХ УПЕРЕДЖУВАЛЬНИХ КУТІВ ВІД ГЕОСТАЦІОНАРНОГО СУПУТНИКА АРТЕМІС КРІЗЬ ХМАРИ}

На розробленій нами системі для телескопа проведені лазерні експерименти з геостаціонарним супутником AРТЕМІС (СКА), які виконувались і в мінливу хмарну погоду. Виявлено, що деяка частина лазерного променя спостерігається одночасно в точці в напрямку вектора швидкості та кута упередження, де супутник був би після часу поширення лазерного світла до телескопа. Ці результати узгоджені з теорією відносності, де аберація світла розраховується при переході від нерухомої до рухомої координатної системи. Результати спостережень дозволяють досліджувати і розробляти системи для компенсації турбулентності атмосфери в точках упередження, які використовуються при лазерній комунікації з наземних станцій до супутників крізь атмосферу.

Ключові слова: астрономія, супутники, лазерне випромінювання, аберація, кути упередження, релятивістські процеси.

\section{В.П. Кузьков ${ }^{1}$, 3. Содник ${ }^{2}$, С.В. Кузьков ${ }^{1}$}

${ }^{1}$ Главная астрономическая обсерватория НАН Украины, ул. Академика Заболотного, 27, Киев, 03680, Украина, тел.: +38 (044) 526-08-69

${ }^{2}$ Европейский космический исследовательский и технологический центр, ЕКА,

Почта 299, 2200 АГ Нурдвик, Нидерланды, тел: +31071 5656565

\section{ПРЯМОЕ ИЗМЕРЕНИЕ ЛАЗЕРНЫХ КОМУНИКАЦИОННЫХ УПРЕЖДАЮЩИХ УГЛОВ ОТ ГЕОСТАЦИОНАРНОГО СПУТНИКА АРТЕМИС СКВОЗЬ ОБЛАКА}

На разработанной нами системе для телескопа проведены лазерные эксперименты с геостационарным спутником АРТЕМИС (ЕКА), которые выполнялись и в переменную облачную погоду. Обнаружено, что некоторая часть лазерного луча наблюдается одновременно в точке в направлении вектора скорости и угла упреждения, где спутник был бы после времени распространения лазерного света до телескопа. Эти результаты находятся в соответствии с теорией относительности, где аберрация света рассчитывается при переходе от неподвижной к подвижной координатной системе. Результаты наблюдений позволяют исследовать и разработать системы для компенсации турбулентности атмосферы в упреждающих точках, используемых при лазерной коммуникации с наземных станций до спутников через атмосферу.

Ключевые слова: астрономия, спутники, лазерное излучение, аберрация, упреждающие углы, релятивистские процессы.

Стаття надійшла до редакції 21.11.16 